\title{
Isolation, Identification and Characterization of Microorganisms Isolated from Unexplored Saline Regions of Kutch, Gujarat, India
}

\author{
Joshi $\mathrm{CM}^{1 *}$ and Trivedi NS ${ }^{2}$ \\ ${ }^{1} \mathrm{C}$ U Shah University, Wadhwan City, Gujarat, India \\ ${ }^{2}$ Gujarat University, Ahmadabad, Gujarat, India \\ *Corresponding Author: Joshi CM, C U Shah University, Wadhwan City, Gujarat, India.
}

\author{
Received: April 11, 2020 \\ Published: June 09, 2020 \\ (C) All rights are reserved by Joshi CM and \\ Trivedi NS.
}

\begin{abstract}
The present investigation reveals the diversity of bacteria, fungus and archaea along the different regions of Kutch area, Gujarat, India. The samples were collected from 3 selected site of Kutch area whose temperature was between $37-41^{\circ} \mathrm{C}, \mathrm{pH} 8.5$, $\mathrm{EC} 1480 \mu \mathrm{s}$, Salinity 9.01 and 1.85 ppm TDS. 52 bacterial, 17 extreme halophilic archaea and 2 halophilic fungus strains were isolated, among these all bacterial strains were selected for further study like enzyme productivity and anti-microbial activity because the main aim of research was to isolate organism which have multiple applications. Fifteen strains produced four or more than four enzymes which have industrial application (amylase, protease, cellulose, lipase, and chitinase) and one strain of Micrococcus showed antimicrobial activity against all test cultures. Eighteen archaea and two halophilic fungi that grew at $25 \%$ salt containing medium were also isolated.

Keywords: Bacteria; Fungus; Archaea; Kutch; Enzyme; Antimicrobial Activity; Salt Concentration
\end{abstract}

\section{Introduction}

Rann of Kutch is a salt marsh in the state of Gujarat, India. It can be divided into the Great and The Little Rann of Kutch. While the Great Rann of Kutch converts to a "White Desert" in the summer with thin layer of salt crust which becomes marshy island during rainy season, little Rann of Kutch represents salt crystallizers of India. On the whole the ecosystem of the Rann is largely undisturbed and would be the reservoir of myriad of microorganisms ranging from normal micro flora to extreme organisms which can thrive in the ever fluctuating harsh saline environments. Such places are always fascinating for understanding the evolution and survival of microbes in such harsh environments.

Lot of work has been done in terms of diversity studies in hyper saline systems. Ventosa [1] have worked on halophiles from unusual habitats, Bacillus iranensis sp. was isolated from saline mud of the hypersaline lake Aran-Bidgol in Iran [2]. In the Indian scenario hypersaline coastal regions of Gujarat, Maharashtra, Rajasthan and Tamil Nadu have been well studied and several Actinobacteria and Halophiles reported [3]. Halophilic Archaebacteria have been reported from desert of Rajasthan (Upasani 2007). Dave and Soni [4] have reported isolation of Halophilic and Alkalophilic bacteria from coastal regions of Gujarat. Thirteen bacterial strains were isolated from Kharaghoda area of Gujarat [5]. More than fifteen isolates were isolated from the different hyper saline soil of Little Rann of Kutch, Gujarat and most of them are used as biofertilizer [6].

Rann of Kutch has also been exploited for the isolation of Extremophiles. Notable studies include those involving isolation of extreme halophiles [7], Halophilic archaebacteria [8], halo tolerant alkaliphilic Streptomyces [9], moderately halophilic bacteria (Dey 2013). All these studies focus on the isolation of microbes using traditional methodology. A very interesting study of Pandit., et al. [10] revealed a diversity of 56 to $87 \%$ Bacteria and 8 to $40 \% \mathrm{Ar}-$ chaea using metagenomics which opened immense possibilities of further work.

In view of the work of Pandit., et al. [10] regarding the immense diversity and presence of genes of industrially important enzymes, this study was formulated to tap the diversity of Rann of Kutch for isolation of industrially important microbes specially focusing on those microbes which have multiple potential of bio-prospecting.

Thus, in this study undisturbed and unexplored soil samples were collected from three locations of Kutch (Sangur village near khavda, Mandvi beach and Great Rann of Kutchh). Microbial isolations were performed for isolation of bacteria, archaea and actinobacteria. These microbes were identified at the molecular level. 
They were then tested for the antimicrobial potential and the ability to produce enzymes including Amylase, Protease, Cellulase, Lipase, and Chitinase [11-28].

\section{Materials and Methods}

Collection of soil samples

Soil samples were collected from different locations on the basis of differences in their physical parameters and to avoid recurrence of identical cultures. The collection sites includes Mandvi beach (N 22. 82513 E 69.33753), and Great Rann of Kutchh (N 23. 82763 E 69.52002) in Kutch area of Gujarat from the depth of 15 $\mathrm{cm}$ in sterile polythene bags and air tight container with the help of sterile spatula and were transported to laboratory for further processing.

\section{Enrichment and isolation}

At first, the soil slurry was made by suspending $1 \mathrm{~g}$ of the collected dry soil in $10 \mathrm{ml}$ distilled water. The slurry was mixed by vortexing for 1 minute, the coarse particles were allowed to settle and serial dilutions were made till $10^{-8} .100 \mu \mathrm{l}$ aliquots of dilutions $10^{-2}, 10^{-4}, 10^{-6}$ and $10^{-8}$ were spread on Starch casein Agar, Nutrient Agar and HV-YPC media in triplicates (A, B and C). All spread plates were incubated at $30^{\circ} \mathrm{C}$ for a period of 14 days. On day 14 , colonies formed were observed and morphologically different colonies were subculture on Starch Casein Agar and HV-YPC media for further characterization and studies.

DNA amplification, sequencing and phylogenetic analysis

Genomic DNA was isolated from the isolates using Qiacube following the protocol given by the manufacturer. Lysis of cultures and chloroform wash were done manually and then the supernatant was subjected to column purification step, washing and elution in Qiacube. The eluted DNA was directly subjected to PCR amplification. Amplification of bacterial isolates was done using 16s universal primers 8F (5'3') and 1492R using touchdown PCR. Similarly, for amplification of Archaea, 21f and 958R were used and fungal DNA was amplified by ITS 1 and ITS 4. The PCR product was detected by agarose gel electrophoresis and was visualized by ultraviolet (UV) fluorescence. PCR products were purified using EXOSAP. Cycle sequencing of purified PCR products was performed using BIGDYE employing same primers except for bacteria, where $704 \mathrm{~F}$ and $907 \mathrm{R}$ primers were used. Cycle sequencing products were purified by using X-terminator and Sam solution. Sequencing was done using the 3500 genetic analyser from Applied Biosystems. Compilation of the individual sequences obtained was done using BIOEDIT software. Sequence homology was done using NCBI BLAST and the organisms were identified. Phylogenetic analysis was performed according to neighbour joining methods using MEGA version 7.0.

\section{Enzymatic study}

The isolates were screened for production of different enzymes using their respective media as mentioned in table 1. For this purpose, cultures were spot inoculated on assay plates and incubated for 4 - 7 days.

\begin{tabular}{|c|c|c|}
\hline $\begin{array}{l}\text { Name of } \\
\text { Enzymes }\end{array}$ & Media & Method \\
\hline Amylase & $\begin{array}{l}\text { Minimal medium } \\
\text { with starch }\end{array}$ & $\begin{array}{l}\text { Clearing around the growth } \\
\text { after flooding with iodine } \\
\text { solution }\end{array}$ \\
\hline Protease & $\begin{array}{l}\text { Casein skim milk } \\
\text { medium }\end{array}$ & Clearing around the growth \\
\hline Cellulase & $\begin{array}{l}\text { Carboxymethyl } \\
\text { Cellulose medium }\end{array}$ & $\begin{array}{l}\text { Clearing around the growth } \\
\text { after flooding with iodine } \\
\text { solution }\end{array}$ \\
\hline Lipase & $\begin{array}{c}\text { Tributyrin Agar } \\
\text { media }\end{array}$ & Clearing around the growth \\
\hline Chitinase & Chitin Agar media & Clearing around the growth \\
\hline
\end{tabular}

Table 1

Experiment was performed in triplicates. After incubation, plates were observed for zone of clearance due to enzyme activity.

\section{Antibiogram analysis}

This screening was done for 52 bacterial isolates. Analysis was done using crude extract obtained by spinning the culture broth at $5000 \mathrm{rpm}$ for 2 minutes. The assay was conducted by agar well diffusion method (Perez., et al. 1990). Test cultures i.e. two gram positive and two gram negative were first spread on nutrient agar plates. Wells were punched using cup-borer and filled with $50 \mu \mathrm{l}$ culture supernatant. Plates were incubated at $30^{\circ} \mathrm{C}$ for 24 hours. Sterile nutrient broth was taken as control. The plates were incubated over night at $30^{\circ} \mathrm{C}$ in incubator. The antimicrobial activity of microbes was analyzed by presence of inhibition zones.

\section{Results}

Physico-chemical properties of the samples

Both soil and water samples were collected from the hypersaline environment of Kutch. The color of water sample was light red to deep red indicating archaeal population. And the muddy soil with dark brown color was collected. The concentration of $\mathrm{NaCl}$ in majority of the water samples collected from hypersaline environments of the Kutch was near saturation, indicating the extremity of the environment. The $\mathrm{pH}$ of the samples varied from location to 
location and ranged from 8.70 to 13.8 . The total dissolved solids (TDS) of brine samples varied from 1.10 to $1.85 \mathrm{ppm}$, electrical conductivity (EC) of water sample varied from was $148 \mathrm{mS} \mathrm{cm}^{-1}$ and that of soil or mud sample was $118 \mathrm{mS} \mathrm{cm}^{-1}$. The temperature of samples ranged from 20 to $26^{\circ} \mathrm{C}$. The properties of the both samples is mentioned in the table 2 .

\begin{tabular}{|c|c|c|}
\hline Sample No. & Sample 1 & Sample 2 \\
\hline Latitude & N 23.82763 & N 22.82513 \\
\hline Longitude & E 69.52002 & E 69.33753 \\
\hline pH & 13.8 & 8.70 \\
\hline Salinity & 10.2 & 8.01 \\
\hline EC & $148.0 \mathrm{mS} \mathrm{cm}^{-1}$ & $118.7 \mathrm{mS} \mathrm{cm}^{-1}$ \\
\hline TDS & $1.85 \mathrm{ppm}$ & $1.14 \mathrm{ppm}^{\circ}$ \\
\hline Temperature & $26.6^{\circ} \mathrm{C}$ & $20.0^{\circ} \mathrm{C}$ \\
\hline
\end{tabular}

Table 2

Isolation of the microorganisms

There were numerous presences of microbes but the organisms with different cultural characteristics were selected. In case of extreme halophiles only colored colonies were counted. The prevalence of hard, sticky colonies was also observed which varied from light pink to cream. Two fungal cultures were also isolated which were found to be grown on the media.

A total of 71 isolates have been obtained in this study including bacteria, halophilic bacteria and archaea. Halotolerant Fungi have also been isolated which could grow on media containing $25 \%$ salt (Table 3).

\begin{tabular}{|c|c|c|}
\hline Sr. No. & Microorganisms & Number of Isolates \\
\hline 1 & Bacteria & 48 \\
\hline 2 & Archea & 13 \\
\hline 3 & Halophilic bacteria & 08 \\
\hline 4 & Halotolerant fungi & 02 \\
\hline
\end{tabular}

Table 3

Identification of isolates based on 16S rRNA sequencing

Identification of isolates on the basis of 16S rRNA sequencing revealed the presence of many different groups of microbes ranging from Bacteria to Archea. Including some common generas like Bacillus, Micrococcus, Staphylococcus, Providencia, Brachybacterium, Virgibacillus, Halobacillus, Haloarcula, Chromohalobacter, Heloferax, Halobacterium, Aspergillus. Table 4 Shows the name of organisms along with their NCBI accession numbers.

\begin{tabular}{|c|c|}
\hline Name of Organism & NCBI Accession number \\
\hline Micrococcus luteus & KY681702 \\
\hline Virgibacillus chiguensis & KY681703 \\
\hline Kokuria palustris & KY681704 \\
\hline Bacillus sonorensis & KY681705 \\
\hline Bacillus infantis & KY681706 \\
\hline Bacillus cereus & KY681707 \\
\hline Bacillus anthracis & KY681708 \\
\hline Haloferax alexendrinus & KY681709 \\
\hline Pseudomonas putida & KY681710 \\
\hline Bacillus foraminis & KY681711 \\
\hline Micrococcus aloeverae & KY681712 \\
\hline Staphylococcus hominis & KY681713 \\
\hline Bacillus licheniformis & KY681714 \\
\hline Bacillus firmus & KY681715 \\
\hline Bacillus anthracis & KY681716 \\
\hline Staphylococcus epidermis & KY681717 \\
\hline Bacillus licheniformis & KY681718 \\
\hline Bacillus oceanisediminis & KY681719 \\
\hline Virgibacillus & KY681720 \\
\hline Bacillus firmus & KY681721 \\
\hline Bacillus siamensis & KY681722 \\
\hline Bacillus velenzensis & KY681723 \\
\hline Bacillus licheniformis & KY681724 \\
\hline Bacillus cereus & KY681725 \\
\hline Staphylococcus epidermis & KY681726 \\
\hline Bacillus endophyticus & KY681727 \\
\hline Bacillus endophyticus & KY681728 \\
\hline Bacillus anthracis & KY681729 \\
\hline Virgibacillus pantothenticus & KY681730 \\
\hline Providencia stuartii & KY681731 \\
\hline Bacillus subtilis & KY681732 \\
\hline Staphylococcus epidermis & KY681733 \\
\hline Bacillus licheniformis & KY681734 \\
\hline Bacillus licheniformis & KY681735 \\
\hline Bacillus licheniformis & KY681736 \\
\hline Bacillus flexus & KY681737 \\
\hline Bacillus thuringiensis & KY681738 \\
\hline Bacillus amyloliquifaciens & KY681739 \\
\hline Bacillus subtilis & KY681740 \\
\hline Brachybacterium paraconglom & KY681741 \\
\hline Micrococcus luteus & KY681742 \\
\hline Micrococcus endophyticus & KY681743 \\
\hline
\end{tabular}




\begin{tabular}{|c|c|}
\hline Bacillus subtilis & KY681744 \\
\hline Bacillus lichenifromis & KY681745 \\
\hline Bacillus licheniformis & KY681746 \\
\hline Staphylococcus sp. & KY681747 \\
\hline Haloferax sp. & KY681748 \\
\hline Haloferax sp. & KY681749 \\
\hline Haloferax volcanii & KY681750 \\
\hline Halobacterium salinarum & KY681751 \\
\hline Halomonas elongate & KY681752 \\
\hline Chromohalobacter salexigens & KY681753 \\
\hline Halobacterium salinarum & KY681754 \\
\hline Haloferax alexendrinus & KY681755 \\
\hline Halobacterium salinarum & KY681756 \\
\hline Haloferax lucentense & KY681757 \\
\hline Halomonas elongate & KY681758 \\
\hline Halomonas elongata & KY681759 \\
\hline Halobacterium salinarum & KY681760 \\
\hline Haloarcula amylolytica & KY681761 \\
\hline Paracoccus sp. & KY681762 \\
\hline Bacillus korlensis & KY681763 \\
\hline Bacillus sp. & KY681764 \\
\hline Bacillus amyloliquifaciens & KY681765 \\
\hline Arthrobacter sp. & KY681766 \\
\hline Halobacillus sp. & KY681767 \\
\hline Arthrobacter sp. & KY681768 \\
\hline Haloferax alexandrinus & KY681769 \\
\hline Halobacterium salinarum & KY681770 \\
\hline Aspergillus versicolor & KY681771 \\
\hline Aspergillus parasiticus & KY681772 \\
\hline
\end{tabular}

\begin{tabular}{|l|c|c|}
\hline Sr. No. & Enzymes & $\begin{array}{c}\text { Number of organisms showing Positive } \\
\text { Result }\end{array}$ \\
\hline 1 & Amylase & 36 \\
\hline 2 & Protease & 40 \\
\hline 3 & Lipase & 33 \\
\hline 4 & Cellulase & 38 \\
\hline 5 & Chitinase & 19 \\
\hline
\end{tabular}

Table 5

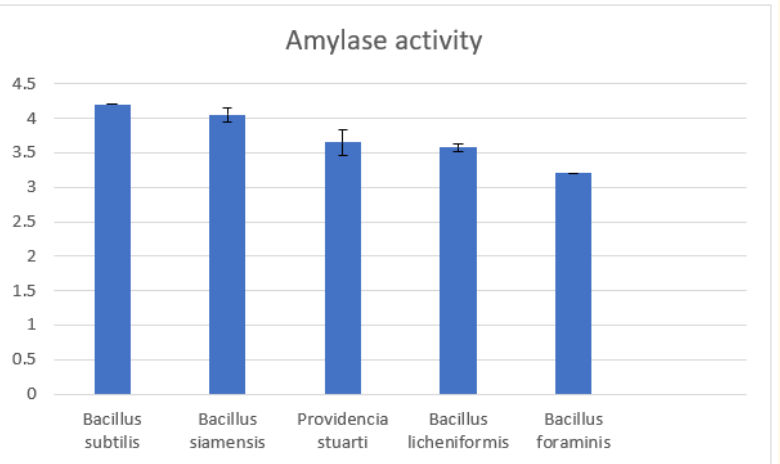

Graph 1: Shows organisms showing maximum amylase activity.

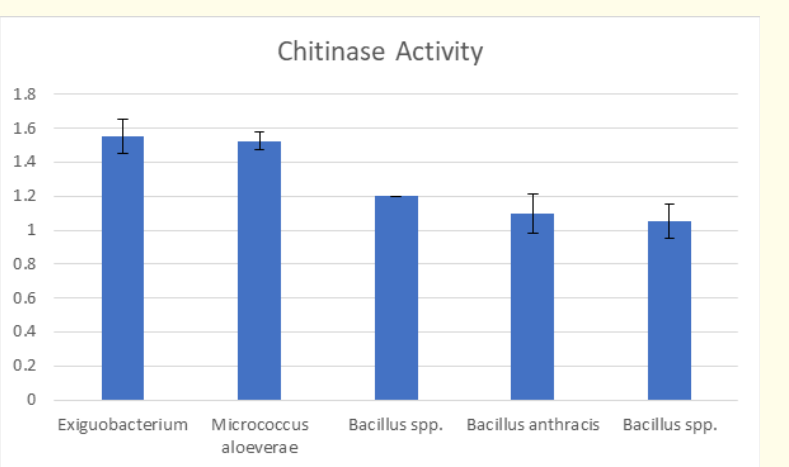

Enzymatic activity

The bacterial isolates were screened for enzymatic and antimicrobial activities. Enzyme screening included industrially important enzymes like Amylase, Lipase, Protease, Cellulase and Chitinase. Maximum isolates were positive for protease activity and minimum number was for Chitinase enzyme (Table 5). The organisms showing maximum enzyme activity was analyzed (Graph 1 to 5 ).

\section{Antimicrobial activity}

Total 48 bacterial cultures were screened for the antimicrobial activity. The activity was observed against two Gram negative and two Gram Positive test organisms. Maximum number of organisms

Graph 2: Shows organisms showing maximum chitinase activity.

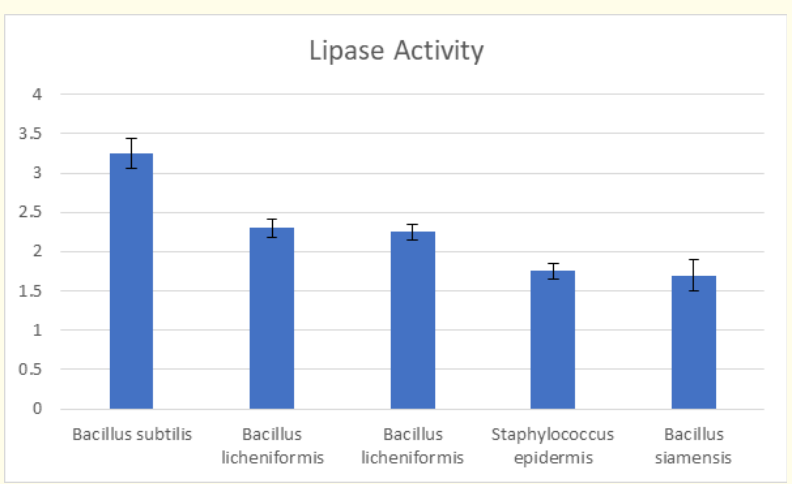

Graph 3: Shows organisms showing maximum lipase activity.

Citation: Joshi CM and Trivedi NS. "Isolation, Identification and Characterization of Microorganisms Isolated from Unexplored Saline Regions of Kutch, Gujarat, India". Acta Scientific Microbiology 3.7 (2020): 03-09. 


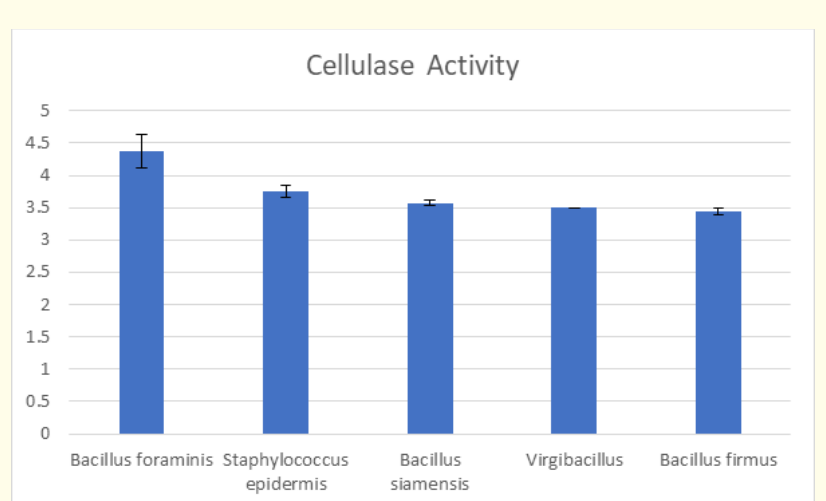

Graph 4: Shows organisms showing maximum cellulase activity.

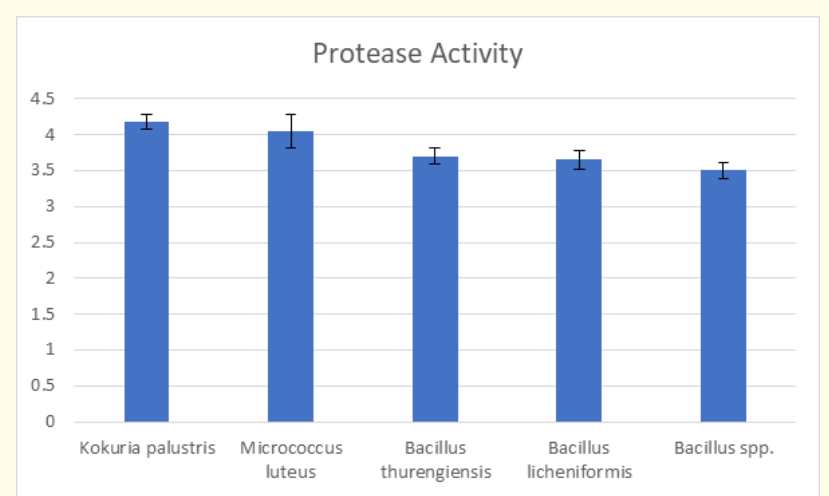

Graph 5: Shows organisms showing maximum protease activity.

were able to show positive activity against Bacillus subtilis and Minimum number of organisms were able to show Positive activity against Enterobacter cloacae.

\begin{tabular}{|l|c|c|}
\hline Sr No. & $\begin{array}{c}\text { Name of Test } \\
\text { Organisms }\end{array}$ & $\begin{array}{c}\text { No. of org. showing } \\
\text { Activity }\end{array}$ \\
\hline 1 & Staphylococcus aureus & 10 \\
\hline 2 & Bacillus subtilis & 47 \\
\hline 3 & Pseudomonas aeruginosa & 06 \\
\hline 4 & Enterobacter cloacae & 01 \\
\hline
\end{tabular}

Table 6: Shows number of organisms showing antimicrobial activity against two gram positive and two gram negative pathogenic strains.

\section{Discussion and Conclusion}

In this study, we provide a preliminary description of a complex community of Microorganisms associated with saline soil of Kutch Gujarat. A total of 71 isolates have been obtained in this study including bacteria, halophilic bacteria and archaea. Halotolerant
Fungi have also been isolated which could grow on media containing $25 \%$ salt.

The bacterial isolates were screened for enzymatic and antimicrobial activities. Enzyme screening included industrially important enzymes like Amylase, Lipase, Protease, Cellulase and Chitinase. Maximum isolates were positive for protease activity and minimum number was for Chitinase enzyme. The results of Amylase has wide range of industrial applications such as food, fermentation, and pharmaceutical industry due to its role in hydrolysis of starch molecules into glucose polymers. Protease is also one of the industrially important enzymes which are mainly used in Detergent, Tannery, Food, Metal recovery and wastewater treatment like industries. Lipase has industrial role in Pharmaceutical, Food, Detergent, Textile, Leather, and Cosmetic like industries. Cellulase is mainly used in pulp and paper, Textile, Bioethanol, Wine and Brewery, Food processing, Agricultural, and animal feed industries. Chitinase has mainly agricultural use chitinase producing organisms are used as bio-fertilizers. As the given organisms have been isolated from the hypersaline soil so they can be used as effective bio-fertilizers in saline regions.

Some of the isolates show the ability to produce multiple enzymes out of 52 bacterial isolates 10 organisms had shown the ability to produce all five enzymes. And 21 isolates had shown the ability to produce four enzymes.

Antimicrobial agents are widely used as pharmaceutical products and they have also been used in bio- pesticides. Many isolates have even shown the antimicrobial activity against both gram negative and gram positive test organisms. Out of 52 bacterial isolates 51 organisms have shown positive activity against Bacillus subtilis, 11 have shown positive activity against Staphylococcus aureus, 6 have shown positive activity against Pseudomonas aeruginosa and 1 have shown positive activity agent Enterobacter cloacae.

From these organisms one organism have also been reported which has ability to produce all 5 enzymes as well as it has shown antimicrobial activity against all sensitive test cultures. That organism has been identified as Micrococcus aloeverae (KY681712). With the use of this multiple ability organism many of the industrial queries can be resolved as many benefits can be obtained from a single organism having both economical and industrial benefits.

Kutch metagenomic studies have shown the presence of wide range of microbes from which few have been isolated and identified in the present study it also reveals the presence different enzymes so those organisms which are still uncultured can be cultured and many different industrially important enzymes can be obtained. 


\section{Bibliography}

1. Ventosa A. "Unusual microorganisms from unusual habitats: hypersaline environments". In: Logan NA, Lappin-Scott HM, Oyston PCF, editors. Prokaryotic diversity-mechanism and significance. Cambridge University Press; Cambridge (2006): 223-253.

2. M Bagheri., et al. "Bacillus iranensis sp. nov., a moderate halophile from a hypersaline lake". International Journal of Systematic and Evolutionary Microbiology 62 (2012): 811-816.

3. Jose PA and Jebakumar SRD. "Phylogenetic diversity of actinomycetes cultured from coastal multipond solar saltern in Tuticorin, India”. Aquatic Biosystems (2012): 8.

4. BP Dave and A Soni. "Diversity of halophilic archaea at salt pans around Bhavnagar coast, Gujarat". Proceedings of the National Academy of Sciences India Section B: Biological Sciences 83.2 (2013): 225-232.

5. JU Vora and HA Modi. "Bacterial diversity of soil samples of saline sites in Kharaghoda (Tehsil-Patdi, District-Surendranagar), Gujarat". International Journal of Research in Pure and Applied Microbiology 3.3 (2013): 102-106.

6. Pravin R., et al. "Microbial Biodiversity Exploration for Liquid biofertilizer Application from Wet Land of Little of Little Rann of Kutch, Gujarat, India". Proceedings of Taal (2012).

7. Pal KK., et al. "Draft genome sequence of Bacillus sp. strain SB47, an obligate extreme halophile isolated from a salt pan of the Little Rann of Kutch, India". Genome Announcement 1.5 (2013): e00816-e00813.

8. Manesh Thomas., et al. "A novel haloarchaeal lineage widely distributed in the hypersaline marshy environment of Little and Great Rann of Kutch in India". Current Science 103.9 (2012): 1078-1084.

9. Thumar JT., et al. "Isolation and partial purification of an antimicrobial agent from halotolerantalkaliphilic Streptomyces aburaviensis strain Kut-8". World Journal of Microbiology and Biotechnology 26 (2010): 2081-2087.

10. Kutch AS Pandit., et al. "Metagenomes from the Saline Desert of Gujarat State Biotechnology Mission". Genome Announcements 2.3 (2014).

11. Vivek Upasani and Suresh Desai. "Sambhar Salt Lake Chemical composition of the brines and studies on haloalkaliphilic archaebacteria". Archives of Microbiology 154 (1990): 589-593.
12. Kamal K Pal., et al. "Draft Genome Sequence of an Extreme Haloarchaeon 3A1-DGR Isolated from a Saltern Crystallizer of the Little Rann of Kutch, India". Indian Journal of Microbiology 54 (2014): 471-473.

13. Sara Cuadros-Orellanaa., et al. "Biodegradation of Aromatic Compounds by a Halophilic Archaeon Isolated from the Dead

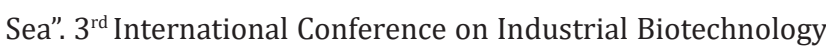
27 (2012).

14. Younes Ghasemia., et al. "Screening and Isolation of Extracellular Protease Producing Bacteria from the Maharloo Salt Lake". Iranian Journal of Pharmaceutical Sciences 7.3 (2011).

15. K Asha., et al. "Isolation and Cultivation of Halophilic Archaea from Solar Salterns Located in Peninsular Coast of India”. The Internet Journal of Microbiology 1.2 (2004).

16. Hassanshahian and Jafar Mohamadian. "Isolation and characterization of Halobacterium salinarum from saline lakes in Iran Mehdi". Jundishapur Journal of Microbiology (2011).

17. Thabet Ibrahim Qassem. "Isolation of Halophilic Microorganisms From salted soil in Jazan area”. Biology Department -Faculty of Science- Jazan University.

18. G Ellis., et al. "Halophilic Archaea determined from geothermal steam vent aerosols". Environmental Microbiology 10.6 (2008): 1582-1590.

19. Stephen Kugbere Agadagba. "Isolation of Actinomycetes from Soil”. Journal of Microbiology Research 4.3 (2014): 136-140.

20. Amit Pandey., et al. "Isolation and Characterization of Actinomycetes From Soil and Evaluation of Antibacterial Activities of Actinomycetes Against Pathogens" International Journal of Applied Biology and Pharmaceutical Technology 2.1 (2011).

21. Anuprita A Deshmukh and Narendra N Vidhale. "Characterization of Novel Antibacterial Actinomycetes Strain N8 from Saline Soil of Vidarbha Region". International Journal of Life Sciences Biotechnology and Pharma Research 4.1 (2015).

22. Department of microbiology, govt. Rajaram college, vidyanagar, Kolhapur, MS, INDIA "Biodiversity of Actinomycetes in Hypersaline soils of Kolhapur district and their screening as potential antibiotic producer, India". Research Journal of Recent Sciences (2012): 317-319.

23. Zuckerkandi E and Pauling L. "Molecules as documents of evolutionary history". Journal of Theoretical Biology 8.2 (1965): 357-366. 
24. Tortoli E. "Impact of genotypic studies on mycobacterial taxonomy: the new mycobacteria of the 1990s". Clinical Microbiology Reviews 16.2 (2003): 319-354.

25. Pfister P., et al. "Role of 16s rRNA helix 44 in ribosomal resistance to hygromycin B". Antimicrobial Agents and Chemotherapy 47.5 (2003): 1496-1502.

26. Woese CR and Fox GE. "Phylogenetic structure of the prokaryotic domain: the primary kingdoms". Proceedings of the National Academy of Sciences 74.11 (1977): 5088-5090.

27. Paula Monteiro de Souza and Pérola de Oliveira Magalhães. "Application of microbial $\alpha$-amylase in industry - A review". Journal of Microbiology 41.4 (2010): 850-861.

28. Houde A., et al. "Lipases and their industrial applications: an overview". Applied Biochemistry and Biotechnology 118.1-3 (2004): 155-170.

\section{Assets from publication with us}

- Prompt Acknowledgement after receiving the article

- Thorough Double blinded peer review

- Rapid Publication

- Issue of Publication Certificate

- High visibility of your Published work

Website: https://www.actascientific.com/

Submit Article: https://www.actascientific.com/submission.php Email us: editor@actascientific.com

Contact us: +919182824667 